\title{
Nutritive Values and Importance of Tropical Green Leafy Vegetables in Human Diet - A Review
}

\author{
A. Beaulah*, C. Rajamanickam and V. Swaminathan \\ Department of Horticulture, Agricultural College and Research Institute, Madurai, India \\ *Corresponding author
}

\begin{abstract}
A B S T R A C T
Greens are among the most productive plants in terms of nutritional value per unit area, because they grow rapidly and can have several crops in a season. They contribute sufficient amounts of vitamin A and C and several minerals even after losing some of the constituents while cooking. The need for green food is being greatly emphasized owing to the increase in knowledge of value of essential minerals and vitamins. They could be used as an important source of nutrients during the pre-cropping season, before traditional crops are available for human consumption. There are hundreds of edible green leafy vegetables grown and used in India. Most common green leafy vegetables grown in tropical areas of India are Amaranthus sp., Alternanthera sessilis, Coriandrum sativum, Hibiscus sabdariffa, Ipomea aquatica, Mentha arvensis, Moringa oleifera, Murraya koenigii, Portulaca aquadrifida, Sauropus androgynous, Sesbania grandiflora, Solanum nigrum, Spinacia oleracea, Talinum traingulare, Trigonella foenum-graecumare used. The nutritional values and chemical constituents present in these green leafy vegetables are of great importance to human health. Consumption of these green leafy vegetables will improve the nutritional status and will reduce the risks of specific diseases like diabetes, cancer and hepatotoxicity. The present study is on reviewing edible green leafy vegetables available in tropical conditions of India and their pharmacological benefits, essential in this modern world to support the benefits of their consumption.
\end{abstract}

\section{Introduction}

India, endowed with climatic conditions provides opportunities for growing an array of green leafy vegetable, which form second important category of vegetables. These green leafy vegetables are mostly rich in essential minerals, vitamins and dietary fibre and have therapeutic properties. With the wake of the novel coronavirus disease (COVID-19) pandemic, there is need to boost our immune systems to prevent from the rate of disease incidence (Padhee and Joanna Kane-Potaka, 2020). Consuming green leafy vegetables are the right and smart way to augment the meet out the nutritional requirements necessary for good health and wellbeing.

Dieticians recommend a daily consumption of at least $125 \mathrm{~g}$ of green leafy vegetables for a balanced diet. There is a wide variation in consumption of green leafy vegetables in 
different parts of the world. Being short duration crop, these can be grown as intercrop or as mixed crop or in roof gardening. As a food source, leafy vegetables are the best source of provitamin $\mathrm{A}$ and $\mathrm{C}$ and also supplies good amounts of iron, folate and other essential minerals. They are also an excellent source of phytochemicals, which aids in fighting against heart disease and cancer.

Majority of the green leafy vegetables belong to Amaranthaceae family. Green leafy vegetables like spinach, amaranthus and gogu are termed as "Poor man's diet" as they are abundantly available all round the year at a very low price and less expensive as compared to other vegetables.

A number of greens are cultivated in India throughout the year. Some are suitable for growing during winter eg. Palak, spinach, fenugreek and mustard and others such as amaranthus, portulaca and poi are suitable for growing during summer. The ten most popular green leafy vegetables are spinach, amaranthus, fenugreek, agathi, mustard, mint, gogu, alternanthera, drumstick leaves and coriander. Besides these, great variety of less familiar green leafy vegetables are also used locally in different parts of the country.

The spinach, amaranth and fenugreek leaves are generally consumed all over the country. Each green leafy vegetable has unique flavour, taste, aroma, depending upon the way it blends with other foodstuffs. Spinach can be used it salt, spicy and sweet food preparations. Some greens like fenugreek, mustard, radish, mint and curry leaves have strong flavour, while other like amaranthus has mild flavour. Gogu, on the other hand, is sour in taste. These leafy vegetables should be included as an essential component of our daily diet.

\section{Nutritional and health benefits of green leafy vegetables}

"Greens" refer to those vegetables grown for their leafy portions for use in both cooking and salads. As a group, they are recognized for their high mineral and vitamin contents; recently, they have gained new popularity from nutrition-conscious consumers. Micronutrient rich green leafy vegetables, the common man's healthy foods, are rightly placed under the category of 'Protective foods' (Table 1).

Dark green leafy vegetables are good sources of minerals like iron, calcium, potassium, and magnesium and vitamins including $\mathrm{K}, \mathrm{C}, \mathrm{E}$, and many of the $\mathrm{B}$ vitamins. They also provide a variety of phytonutrients including beta-carotene, lutein, zeaxanthin, and Omega3 fatty acid which protect cells from damage and age-related problems (Sreenivasa Rao, 2017). Greens have very little carbohydrate in them and the carbohydrate is packed in layers of fibre, which make them very slow to digest and have very little impact on blood glucose.

Edelman and Colt (2016) reported that protein content of green leafy vegetables such as spinach (Spinacia oleracea), broccoli (Brassica oleracea var. Italic) and duckweed (Lemna perpusilla) provide all the essential amino acids that meet the FAO nutrition standards.

Indian Green leafy vegetables such as basella (Basella rubra), fenugreek (Trigonella foenum graecum), hibiscus (Hibiscus cannabinus), coriander (Coriandrum sativum), cabbage (Brassica oleracea) and spinach (Spinacia oleracea) are good sources of soluble dietary fiber content. Consumption of higher levels of vegetable fiber resulted in reduced risk of cardiovascular diseases and possibly, colon cancer (Jenkins, 2001) 
Most sources seem to agree on the excellent nutritional benefits of moringa (Folkard and Sutherland, 1996).

The moringa leaves provide many vitamins and minerals and can be consumed in cooked or dried forms. The foliage is comparable to spinach in both its appearance and nutritional quality. Nearly 46 Antioxidants and 36 AntiInflammatory compounds are available in the moringa plant. The more antioxidants in the body, the less is the aging and disease occurrence (Beaulah, 2016).

Green leafy vegetables are abundant sources for $\beta$-carotene. In leaves, vitamin $A$ is present in the form of provitamin A carotenoids such as $\beta$-carotene (ca. 25-30\%), $\alpha$-carotene, $\gamma$ carotene, $\beta$-cryptoxanthin and non-provitamin A carotenoids lutein (ca. 45\%), violaxanthin (ca. 15\%) and neoxanthin (ca. 15\%)(Britton, 1996).

\section{Medicinal importance of green leafy vegetables}

Leafy vegetables are ideal for weight management as they are typically low in calories. They are useful in reducing the risk of cancer and heart disease since they are low in fat, high in dietary fibre, and rich in folic acid, vitamin $\mathrm{C}$, potassium and magnesium, as well as containing a host of phytochemicals, such as lutein, beta-cryptoxanthin, zeaxanthin, and beta-carotene. Most studies have established that intakes of green leafy vegetables reduce cardio vascular diseases (Wang et. al., 2016) (Table 2).

In Spain, Stephen Daniells (2008) suggested that an increased intake of green leafy vegetables, but not fruit, may reduce the risk of lung cancer by 50 per cent.

Because of their high magnesium content and low glycemic index, green leafy vegetables are also valuable for persons with type 2 diabetes. An increase of one serving / day of green leafy vegetables were associated with a nine per cent lower risk of diabetes.

The high level of vitamin $\mathrm{K}$ in greens makes them important for the production of osteocalcin, a protein essential for bone health. The risk of hip fracture in middle-aged women was decreased 45 per cent for one or more servings / day of green leafy vegetables compared to fewer servings (Diane Feskanich et al, 1995).

Lutein and zeaxanthin, carotenoids found in dark-green leafy vegetables, are concentrated in the eye lens and macular region of the retina, and play a protective role in the eye. They protect against both cataract and agerelated macular degeneration, the major cause of blindness in the elderly. Millions of children around the world have an increased risk of blindness, and other illnesses because of inadequate dietary vitamin A from green leafy vegetables.

Green leafy vegetables contain a variety of carotenoids, flavonoids and other powerful antioxidants that have cancer-protective properties. In a study, it was reported that eating 3 or more servings a week of green leafy vegetables significantly reduced the risk of stomach cancer, the fourth most frequent cancer in the world.

Cabbage, cauliflower, brussels sprouts, and broccoli are rich in indoles and isothiocyanates, which provide protection against colon and other cancers. Broccoli sprouts have been reported to contain 10 or more times as much sulforaphane, a cancerprotective substance, than mature broccoli. A higher consumption of green leafy vegetables has been shown to significantly decrease the risk of breast and skin cancer. 


\section{Commercially important green leafy vegetables}

\section{Amaranthus}

Amaranth is one of the ancient groups of plants having great potential for combating under-and mal-nutrition in dietary. It is also called "poor man's spinach", and is the most common leafy vegetable grown in India during summer and rainy season. Being a very fast growing short duration crop with high yield potential of edible matter per unit area, it fits well in a crop rotation. About 60 species of amaranthus is widely distributed throughout the world in tropical, subtropical and temperate regions. Among them, Amaranthus tricolor, A. blitum and A. tristis are cultivated in India. Leafy type amaranth is usually grown in kitchen and market gardens and the grain types as mixed crops along with cereals, pulses and vegetables.The fresh tender leaves and its stem are delicious when cooked like other fresh leafy vegetables. The tiny seeds of grain amaranthus are popped or parched and milled for flour or gruel. Compared to spinach, Amaranthus contains three times more vitamin $\mathrm{C}$, calcium and niacin. Compared to lettuce, grain Amaranthus contains 18 times more vitamin A, 13 times more vitamin C, 20 times more calcium and 7 times more iron (Guillet, 2004). A study by Allemann et al.(1996) showed that amaranth has the potential to be a valuable source of nutrition in areas in Africa with hot, dry climates. The crop can grow on marginal lands and when it gets well established it can withstand acute drought conditions.

\section{Alternanthera}

Alternanthera sessilis belongs to the family Amaranthaceae is an important green leafy vegetable species typically growing on disturbed areas and in wetland habitats, and regarded as a fast-growing highly invasive weed. It is adapted to grow on a range of soil types ranging from poor sandy or alkaline soils, to loam or black cotton soils. In tamil it is known as ponnankanni keerai. It is also able to grow in seasonally-waterlogged areas as well as in areas with extreme dry conditions (Holm et al., 1997). A. sessilis can be found invading floodplain wetlands, margins of rivers, streams, canals, ditches, ponds, reservoirs, tanks, marshes, swamps, wet low-lying ground, ephemeral pools, seasonal pans and damp forest. This species is also a weed in fields with sorghum, millet, Eleusine spp., maize, cotton, cassava, cereal crops, pastures, and vegetable farms (Gupta, 2014). Leaves are fried with ghee, which gives cooling effect to eyes, disease free life. It acts as a good anti-oxidant. A. sessilis leaves relieve floating abdomen, liver diseases and vatha diseases (Mudhaliar, 1988). The leaves are very effective in treating in cuts and wounds, antidote for snake bite and scorpion sting and skin disease

\section{Basella}

Basella or vine spinach is a popular tropical leafy-green vegetable, commonly grown as backyard herb in the home gardens. Vinespinach belongs to the Basellaceae family and has two chief cultivars, Basella alba, which features green- stems and deep-green leaves, and Basella rubra with purplish stems and dark green leaves with pink veins. It is native to South Asia, probably originated in the monsoon fed tropical regions of Malabar Coast of India and Sri Lanka. In Asia, basella is identified by different names in countries. It is different from English spinach (Spinacea oleracea) in that the vine spinach is a creeping vine with bright, broad, dark green, thick, and mucilaginous leaves (Sanderson et al., 20005). Fresh leaves, particularly of basella rubra, are rich sources of several vital carotenoid pigment anti-oxidants such as $B$ - 
carotene, lutein, zeaxanthin. Together, these compounds help act as protective scavengers against oxygen-derived free radicals and reactive oxygen species (ROS) that play a healing role in aging and various disease processes.

\section{Coriander}

Coriander (Coriandrum sativum), belongs to the family apiaceae is considered to be appetizing, cool, digestive and better for vision. It can be used in many ways in our daily diet. It contains iron, vitamin $\mathrm{C}$, vitamin A, calcium and phosphorus. Shredded coriander added to vegetables and other foodstuffs gives special flavor to food items, making them more digestible. Coriander seed and herb essential oils have been actively investigated for their chemical composition and biological activities including antimicrobial, antioxidant, hypoglycemic, hypolipidemic, anxiolytic, analgesic, antiinflammatory, anti-convulsant and anti-cancer activities, among others. A very good food for digestive system, coriander promotes liver functions and bowel movements (Laribi et al., 2015). Coriander leaves are good for diabetic patients as it can stimulate insulin secretion and lower the blood glucose level.

\section{Gogu}

Hibiscus sabdariffa, a member of Malvaceae family, is a known medicinal plant with a worldwide fame (Abbas et al., 2011) and the plant can be found in almost all warm countries such as India, Saudi Arabia, Malaysia, Indonesia, Thailand, Philippines, Vietnam, Sudan, Egypt and Mexico (Chewonarin et al., 1999). Roselle is mainly cultivated to be consumed and the main producers of Roselle blossoms are Egypt, Sudan, Mexico, Thailand and China. Other hibiscus varieties are planted for their fibers they produce. It is commonly known as Gogu.
In gogu (Hibiscus sabdariffa), tender young leaves and stems are used either raw or cooked. Used in salads, as a potherb and as a seasoning in curries, they have an acid, rhubarb-like flavor. The leaves are antiscorbutic, emollient, diuretic, refrigerant, and sedative. The leaves are very mucilaginous and are used as an emollient and as a soothing cough remedy. They are used externally as a poultice on abscesses.

\section{Water spinach}

Water spinach (Ipomoea aquatica), also known as kangkong, water glorybind, water convolvulus, and swamp cabbage is an important green leafy vegetable in Southeast Asia belongs to the family Convolvulaceae. It is speculated to have originated in India but is now widely grown throughout the tropics. All parts of the young plants are eaten (Candish et al., 1987). The crop is fragile and requires rapid and careful handling to minimize damage and wilting. It is taken like cooked spinach and canned product is often available in ethnic markets (Rao and Tuhina, 2002).

\section{Curry leaf}

Curry leaf botanically Murraya koenigii, belongs to the family Rutaceae is highly valued for seasoning in South Indian and Sri Lankan cooking, much like bay leaves especially in curries with fish or coconut milk. In their fresh form, they have a short shelf life though they may be stored in a freezer for quite some time, though they lose much of flavor. They are also available dried, though the aroma is much inferior. The leaves are also used as a herb in ayurvedic medicine. Their properties include antidiabetic, antioxidant, antimicrobial, anti-inflammatory, hepatoprotective, anti-hypercholesterolemic etc,. Aromatic bioactive constituents in the leaves of $M$. koenigii retain their flavor and other qualities, even after drying (Yankuzo, et 
al. 2011). M. koenigii leaves are slightly bitter in taste, pungent in smell, and weakly acidic. They are used as antihelminthics, analgesics, digestives, and appetizers in Indian cookery (Bhandari, 2012).

\section{Moringa}

Moringa is a remarkable discovery which can make a tremendous difference in health and quality of life. Mounting scientific evidence shows what has been known for thousands of years by people in the tropical parts of the world: Moringa is nature's medicine cabinet. Moringa oleifera, belongs to the family moringaceae is a candidate in the fight against malnutrition. A group of health workers from the Church World Service have been utilizing this highly nutritious and fast growing tree as a means to cure and prevent malnutrition in infants, pregnant and lactating women as an alternative to the classic and expensive condiments usually used such as whole milk powder, sugar, vegetable oil, and sometimes peanut butter. It takes around ten days to see an improvement in malnourished infants when moringa leaves are used whereas it takes months for recovery with conventional methods.

According to Fuglie (2003), the West Africa representative of the Church World Service who used the Moringa tree as a base for a nutrition programme, "for a child aged 1-3, a $100 \mathrm{~g}$ service of fresh cooked leaves world provide all daily requirements of calcium, about $75 \%$ of iron and half protein needs, as well as important amounts of potassium, B vitamins, copper and all the essential amino acids. As little as $20 \mathrm{~g}$ of leaves would provide a child with all the vitamins $\mathrm{A}$ and $\mathrm{C}$ he needs.

For pregnant and breast-feeding women, moringa leaves and pods can do much to preserve the mother's health and pass on strength to the fetus or nursing child. One 100 g portion of leaves could provide a woman with over a third of her daily need of calcium and give her important quantities of iron, protein, copper, sulphur and B-vitamins. One rounded tablespoon $(8 \mathrm{~g})$ of leaf powder will satisfy about 14 per cent of the calcium, and 23 per cent of the iron and nearly all the vitamin A needs for a child aged 1-3. Six rounded spoonfuls of leaf powder will satisfy nearly all of a woman's daily iron and calcium needs during pregnancy and breastfeeding.

\section{Puslane}

Purslane (Portulaca oleracea) is by known various names such as kitchen purslane, garden purslane, and in Spanish, verdolaga. Purslane is a popular vegetable in France, several other European countries, and Africa, especially in Egypt and Sudan. There are many different types worldwide and is believed to have originated in India, South Russia and South America. It is distributed widely in the tropical and subtropical areas of the world including many parts of the United States. It is eaten extensively as a potherb and is added to soups and salads around the Mediterranean and tropical Asian countries. Its soft stem and leaves are used raw, alone or with other greens (Palanisamy et. al. 2002). Purslane is also used for cooking or used as a pickle. Purslane is a dwarf creeping annual herb with small fleshy leaves. Purslane is found growing in orchards, crop fields throughout India, commonly in temperate and subtropical Himalaya.

The leaves are usually stripped from the stems and are prepared like spinach. The taste is a cross between watercress and spinach. An undesirable quality of purslane is that its foliage, like that of spinach, contains oxalic acid and tends to accumulate nitrates. 


\section{Chekurmanis}

Chekurmanis (Sauropus androgynous) contains atleast seven active compounds that can stimulate synthesis of steroid hormones such as progesterone, astradiol, testosterone, glukokortikoid and the compound eikosanoid including prostaglandin, prostasiklin, tromboksan, lipoksin, leukotrien. If the women consume, the active compound in the leaves will spur the formation of hormones, femininity, so the skin becomes smooth and stimulates healthy and soft hairs for women. Conversely, in the body of the male, leaves will stimulate formation of the hormone, which will boost sexual vitality. Chekurmanis is praised for restoration of vitality and men fertility (Petrus, 2012).

\section{Agathi}

Many green leafy vegetables have got medicinal values, among them, Sesbania grandiflora, often described as "A green leaf with curative benefits", is a relatively unknown plant which is not easily available outside tropical countries. Although Agathi trees are widely distributed in India, it is not so popular among the people. It is cultivated in states like Assam, Bengal, Punjab, Andhra Pradesh and Tamil Nadu. In the indigenous system of medicine in India, the plant Agathi is claimed to be useful for various ailments and one such is for the treatment of renal calculi. Generally the green leaves of this variety is used for cooking similar to spinach but the flower, leaf and bark of Agathi tree has got a number of medicinal properties which is used in various ayurvedic and other traditional medicines. The simplest manner in which these leaves are used is by boiling the leaves with water to make a tea, which bears antibiotic, antihelminthic and antitumoral properties. For all sorts of sprains and bruises, crushed leaves of Sesbania grandiflora crushed leaves can be applied and the juice acts as a good medical treatment. It is also used as an antidote for poisons. The plant has various uses in folk and traditional medicines for head ache, swellings, anemia, bronchitis, pain and tumors (Pradheep Karmarkar et al., 2016).

\section{Black nightshade}

Black nightshade (Solanum nigrum) leaves when taken internally in very small amounts. Strongly promote perspiration and purge the bowels the next day. The juice of the fresh herb is sometimes used for fever and to allay pain. In large doses, black nightshade can cause serious, but usually not fatal, poisoning. Externally, the juice or an ointment prepared from the leaves can be used for skin problems and tumors. The berries are poisonous, but boiling apparently destroys the toxic substances and makes them usable for preserves, jams, and pies (Kouadio et al., 2019).

The fruits is used as a cosmetic; rubbing the seeds on the cheeks to remove freckles. Children harmlessly and extensively eat the mature fruit. The fruit has been used for diabetes. Decoction of stalk, leaves, roots are good for wounds and cancerous sores. An infusion of the plant is used as an enema in infants having abdominal upsets. Freshly prepared extract of the plant is effective in the treatment of cirrhosis of the liver and also serves as an antidote to opium poisoning.

\section{Spinach}

Spinach (Spinacia oleracea) is known as a rich source of iron and calcium. According to the United States Department of Agriculture, a 180 gram serving of boiled spinach contains $6.43 \mathrm{mg}$ of iron, whereas one 6.oz. (170g) around hamburger patty contains at most 4.42 mg. Thus spinach does contain a relatively high level of iron, compared to other 
vegetable and meat sources. The iron in spinach is poorly absorbed by the body unless eaten with calcium. The spinach contains high levels of oxalate. Oxalates bind to iron to form ferrous oxalate, thus making the iron in spinach unavailable, plus high amounts of oxalates remove iron from the body. Therefore, a diet high in oxalate (or phosphate or phytate) leads to a decrease in iron absorption. As a result around 90 per cent of the iron content in spinach will be released in urine, and not absorbed in the body.

Spinach is regarded as the most esteemed green leafy vegetables among all. It's cooling and nutritive content helps in eliminating cough, asthma and other toxic elements. Spinach contains iron, folic acid, vitamin A and essential amino acids in major quantities along with potassium, sulphur, silicon, magnesium and sodium in minor quantities. Spinach helps in reducing acidity problems in people, bestowing improved health. Spinach juice is diuretic, allaying bile disorders. Intake of spinach provides satisfactory result in case of anaemia.

It is highly effective in curing generic aliments. Spinach also has a high calcium content. However, the oxalate content in spinach binds with calcium de creasing its absorption. By way of comparison, the body can absorb about half of the calcium present in broccoli, yet only around 5\% of the calcium in spinach. Spinach has a large nutritional value, especially when fresh, steamed, or quickly boiled. It is a rich source of vitamin $\mathrm{A}$, vitamin $\mathrm{C}$, vitamin $\mathrm{E}$, vitamin $\mathrm{K}$, magnesium and several vital antioxidants. Recently, opioid peptides called rubiscolins have also been found in spinach. It is a source of folic acid (vitamin B9) and this vitamin was first purified from spinach. To benefit from the folate in spinach, it is better to steam it than to boil it. Boiling spinach for four minutes can halve the level of folate. When cooked, the volume of spinach is decreased by three quarters. Spinach is an excellent source of vitamin $\mathrm{K}$, vitamin $\mathrm{A}$, manganese, folate, magnesium, iron, vitamin $\mathrm{C}$, vitamin B2, calcium, potassium and vitamin B6. It is a very good source of dietary fibre, copper, protein, phosphorus, zinc and vitamin E. In addition, it is a good source of omega -3 fatty acids, niacin and selenium.

\section{Ceylon Spinach}

Talinum triangulare (Jacq.) Willd. (Family: Portulaceae), is commonly called waterleaf / ceylon spinach. It is an herbaceous, annual, coalescent, and glabrous plant widely grown in tropical regions as a leafy vegetable. In Nigeria, it is consumed as a leafy vegetable and constituent of sauces (or vegetable soups). Nutritionally, it is a good source of some minerals (e.g., calcium, magnesium, and potassium) and vitamins (e.g., ascorbic acid and pyridoxine) (Oguntona, 1998). The extract from the leaves and roots is used to cure asthma (Ogie- Odia and Oluowo, 2009). According to Ofusori et al., (2008), "waterleaf consumption has benefiting effects on the neurons of the cerebrum and may probably enhance the cognitive ability in Swiss albino mice". In Edo State, Nigeria, Talinum triangulare is used as a diuretic, and for the management of gastrointestinal disorders (Mensah et al., 2008). It is also used to treat Shistosomiasis, scabies, fresh cuts, high blood pressure, and anemia (Ogunlesi et al., 2010).

Presently it is cultivated as a minor vegetable in India, Malaysia, Indonesia, Tropical Africa, Arabian countries and West Indies. It is a soft musilaginous leafy vegetable suitable for cultivation under other crop canopy. It is a shade loving plant grown for its tender shoots and leaves. It is therefore most suitable for areas with high vegetation and crop canopy. 
Table.1 Nutritional contents of leafy vegetables

\begin{tabular}{|c|c|c|c|c|c|c|c|c|c|c|c|c|c|c|c|c|}
\hline Crop & $\begin{array}{c}\text { Water } \\
(\%)\end{array}$ & $\begin{array}{c}\text { Engy } \\
\text { (K } \\
\text { cal) }\end{array}$ & $\begin{array}{l}\text { Protein } \\
\text { (g) }\end{array}$ & $\begin{array}{c}\text { Fat } \\
\text { (g) }\end{array}$ & $\begin{array}{c}\text { Carbboh } \\
\text { ydrate (g) }\end{array}$ & $\mathbf{A}(\mathbf{I U})$ & $\mathrm{C}(\mathrm{mg})$ & $\begin{array}{c}\text { Thiamin } \\
\text { (mg) }\end{array}$ & $\begin{array}{c}\text { Riboflavi } \\
\text { n (mg) }\end{array}$ & $\begin{array}{l}\text { Folate } \\
\text { (mcg) }\end{array}$ & $\begin{array}{c}\text { Niacin } \\
\text { (mg) }\end{array}$ & $\begin{array}{c}\text { Ca } \\
(\mathbf{m g})\end{array}$ & $\begin{array}{c}\mathbf{P} \\
(\mathbf{m g})\end{array}$ & $\begin{array}{c}\mathbf{F e} \\
(\mathbf{m g})\end{array}$ & $\begin{array}{l}\mathrm{Na} \\
(\mathrm{mg})\end{array}$ & $\begin{array}{c}\mathbf{K} \\
(\mathbf{m g})\end{array}$ \\
\hline Amaranth & 92 & 23 & 2.5 & 0.3 & 4.0 & 2,900 & 43 & 0.03 & 0.16 & 85 & 0.7 & 215 & 50 & 2.3 & 20 & 611 \\
\hline $\begin{array}{l}\text { Alternanthr } \\
\text { a }\end{array}$ & 80 & 251 & 4.7 & 0.8 & 11.8 & 192 & 17 & - & 0.14 & - & 1.2 & 146 & 45 & 60 & 37 & 891 \\
\hline Basella & 92 & 19 & 1.8 & 0.3 & 3.4 & 8000 & 102 & 0.05 & 0.15 & 140 & 0.5 & 0.58 & 0.24 & 0.37 & 0.52 & 0.79 \\
\hline Coriander & 7 & 279 & 2.1 & 0.52 & 3.67 & 337 & 27 & 0.06 & 0.16 & 62 & 1.14 & 67 & 48 & 1.77 & 46 & 521 \\
\hline Gogu & 6.5 & 399 & 20.9 & 21.3 & 30.9 & - & - & - & - & & & & & & & \\
\hline $\begin{array}{l}\text { Water } \\
\text { spinach }\end{array}$ & 72.0 & 19 & 2.6 & - & 3.14 & 6300 & 55 & 0.03 & 0.10 & 57 & 0.90 & 416 & 409 & 1.67 & 113 & 312 \\
\hline Curry leaf & 63.8 & 108 & 6.1 & 1.0 & 18.7 & 600 & 4.0 & 0.08 & 0.21 & 93.9 & 2.3 & 830 & 57 & 0.93 & - & - \\
\hline Moringa & 75 & 92 & 6.7 & 1.7 & 13.4 & 11300 & 220 & 0.06 & 0.05 & 0.9 & 0.3 & 440 & 70 & 7.0 & - & 25.9 \\
\hline Purslane & 94 & 16 & 1.3 & 0.1 & 3.4 & 1,320 & 21 & 0.05 & 0.11 & 12 & 0.5 & 65 & 44 & 2.0 & 45 & 494 \\
\hline $\begin{array}{l}\text { Chekkurma } \\
\text { nis }\end{array}$ & 73.6 & 103 & 6.8 & 3.2 & 11.6 & 5706 & 247 & 0.48 & 0.32 & - & 2.6 & 570 & 200 & 28 & - & - \\
\hline Agathi & 73.1 & 321 & 8.4 & 1.4 & 47.1 & 9000 & 169 & 0.21 & 0.09 & - & 1.2 & 1130 & 80 & 3.9 & - & - \\
\hline $\begin{array}{l}\text { Black shade } \\
\text { night }\end{array}$ & 84.0 & 298 & 18.2 & 8.5 & 37.2 & 2000 & 35.18 & 0.15 & 0.15 & 11.60 & 1.2 & 4421 & 0.23 & 496 & 0.06 & 3.08 \\
\hline $\begin{array}{l}\text { Ceylon } \\
\text { spinach }\end{array}$ & 87.6 & 44 & 2.6 & 4.8 & 2.1 & 265 & 49 & 0.03 & 0.17 & - & 0.45 & - & 0.40 & 0.02 & 0.37 & 0.33 \\
\hline Methi & 86.1 & 49 & 4.4 & 0.9 & 6.0 & 2340 & 52 & 0.04 & 0.31 & - & 0.8 & 395 & 51 & 1.93 & 76.1 & 31.0 \\
\hline
\end{tabular}


Table.2 Medicinal uses of green leafy vegetables

\begin{tabular}{|c|c|c|}
\hline Common Name & Scientific Name & Medicinal properties \\
\hline Amaranthus & Amaranthus. sp & $\begin{array}{l}\text { Lowers body heat } \\
\text { Improves digestion } \\
\text { Reduces colon cancer } \\
\text { Cures diarrhoeal disorders }\end{array}$ \\
\hline Ponnankanni & Alternanthra sessilis & $\begin{array}{l}\text { Cures asthma } \\
\text { Cures Hepatitis } \\
\text { Reduces lung troubles } \\
\text { Used as hair tonic }\end{array}$ \\
\hline Basella & Basella alba & $\begin{array}{l}\text { Gastro protective activity } \\
\text { Heals ulcers } \\
\text { Anti - inflammatory property } \\
\text { Heals wounds } \\
\text { Improves testosterone levels in males } \\
\text { Safe laxative }\end{array}$ \\
\hline Coriander & Coriandrum sativum & $\begin{array}{l}\text { Cures spasms } \\
\text { Stimulates appetite } \\
\text { Expels flatulence and gripping pains from } \\
\text { stomach } \\
\text { Cures giddiness } \\
\text { Improves digestion } \\
\text { Avoids vomiting } \\
\text { Improves digestion } \\
\text { Increases secretion of urine } \\
\text { Reduces fever } \\
\text { Cures skin disorders allergies skin rashes, itch, } \\
\text { inflammation sting and insect bites } \\
\text { Cures dysentry, hepatitis, indigestion, nausea, } \\
\text { typhoid and bleeding in nose } \\
\text { Reduces body heat }\end{array}$ \\
\hline Hibiscus & Hibiscus sabderiffa & Prevents scurvy \\
\hline Water Spinach & Ipomoea aquatica & $\begin{array}{l}\text { Cures piles } \\
\text { Reduces blood pressure } \\
\text { Treats jaundice } \\
\text { Prevents nervous debility }\end{array}$ \\
\hline Curry leaf & Murraya koenigii & $\begin{array}{l}\text { Cures digestive disorders } \\
\text { Cures diabetes } \\
\text { Prevents cataracts } \\
\text { Cures anorexia } \\
\text { Cures itching and inflammation } \\
\text { Cures diarrhoea and dysenty }\end{array}$ \\
\hline Moringa & Moringa oleifera & Cures scurvy, jaundice and diabetes \\
\hline Purslane & Portulaca oleracea & $\begin{array}{l}\text { Treatment of burns } \\
\text { Cures headache }\end{array}$ \\
\hline
\end{tabular}




\begin{tabular}{|c|c|c|}
\hline & & $\begin{array}{l}\text { Prevents arthritis } \\
\text { Cardiac tonic } \\
\text { Muscle relaxant }\end{array}$ \\
\hline Chekurmanis & $\begin{array}{l}\text { Sauropus } \\
\text { androgynus }\end{array}$ & $\begin{array}{l}\text { Lowers body heat } \\
\text { Strengthens body } \\
\text { Prevents anaemia } \\
\text { Prevents constipation } \\
\text { Cures skin disease } \\
\text { Cures eye disease } \\
\text { Improves growth and mental stability }\end{array}$ \\
\hline Agathi & Sesbania grandiflora & $\begin{array}{l}\text { Cures stomach pain } \\
\text { Increases secretion of milk } \\
\text { Cures cough and cold }\end{array}$ \\
\hline Black nightshade & Solanum nigrum & $\begin{array}{l}\text { Quick healing } \\
\text { Lowers body heat } \\
\text { Prevents constipation and diarrhoea } \\
\text { Cures skin disease } \\
\text { Cures jaundice } \\
\text { Improves body colour }\end{array}$ \\
\hline Spinach & Spinach oleracea & $\begin{array}{l}\text { Cures arthritis } \\
\text { Cures anaemia } \\
\text { Prevents cough and influenza } \\
\text { Prevents constipation } \\
\text { Cures headache }\end{array}$ \\
\hline Ceylon spinach & Talinum triangulare & $\begin{array}{l}\text { Effective for treating liver diseases } \\
\text { Suitable for tackling hepatic ailments } \\
\text { Prevents anaemia } \\
\text { Boosts the blood level } \\
\text { Aids Easy Digestion } \\
\text { Laxative Effects }\end{array}$ \\
\hline $\begin{array}{l}\text { Fenugreek } \\
\text { (methi) }\end{array}$ & $\begin{array}{l}\text { Trigonella foenum- } \\
\text { graecum }\end{array}$ & $\begin{array}{l}\text { Mild laxative } \\
\text { Soothing for nerves } \\
\text { Alleviates anaemia } \\
\text { Cures diabetes } \\
\text { Cures mouth ulcers, bad breath, stomach and } \\
\text { respiratory disorders } \\
\text { Cures night blindness } \\
\text { Cures giddiness } \\
\text { Cures stomach disorders }\end{array}$ \\
\hline
\end{tabular}




\section{Fenugreek}

Fenugreek (Trigonella foenum graecum) is known as nature's great boon, bearing excellent medicinal value. Regular use of fenugreek leaves helps in keeping the body healthy and problem free. It is rich in calcium, iron and protein and phosphorus. It also contains minerals and vitamins in high quantity.

It is regarded as a great appetizer. It helps in curing dyspepsia, cough, piles, vomiting, rheumatism and intestinal worms. Paste of fenugreek applied on hair scalp lengthens the hair, preserve its natural colour and keeps them silky soft. If applied on face; prevents pimples, blackheads and early appearance of wrinkles. It also improves complexion and makes one look years younger.

\section{Points to be considered before cooking Green Leafy vegetables}

The leafy vegetables should be washed thoroughly before chopping, particularly when used as salad.

To prevent the loss of water soluble vitamins, the green leafy vegetables are not soaked in water.

Minimum amount of water should be used for cooking. The cooking has to be for a short time in a covered vessel.

The water in which the leafy vegetables have been cooked can be used in dhals and soups.

Cooking of leafy vegetables in the presence $f$ oil helps in the retention of b-carotene and the presence of an acidic medium helps in reducing the b-carotene loss.

Deep frying of leafy vegetables should be avoided and cooking can be by boiling method to retain most of the nutrients.

\section{Antinutritional factors in green leafy vegetables}

Green leafy vegetables may also contain many toxic substances, which are harmful for human health. The toxic amaranthus, portulaca, celosia and basella, and nitrates, saponins and oxalates in spinach as moringa leaves had negligible amounts of tannins (12 $\mathrm{g} / \mathrm{kg})$, saponin $(80 \mathrm{~g} / \mathrm{kg})$, phytate $(21 \mathrm{~g} /$ $\mathrm{kg}$ ). Excess consumption of these leafy vegetable may cause disorder.

\section{Future thrust}

The major nutrition-related public health problems include a) chronic energy deficiency and under-nutrition, b) micro-nutrient deficiencies like anaemia due to iron and folic acid deficiency, vitamin A deficiency and iodine deficiency disorders and c) chronic energy excess and obesity. The National Nutrition Policy adopted in 1993 advocates a comprehensive intersectoral strategy for alleviating the multifaceted problem of malnutrition and achieving an optimal state of nutrition for all sections of the society. Even then the target could not be achieved. To solve the problem of malnutrition the following measures can be taken up.

The research results revealed that dark-green leafy vegetables made a significant contribution towards total nutrient intake of two-to five year-old children for several of the micronutrients. This contribution can potentially be increased and these vegetables be consumed more frequently and by a larger proportion of the children. This can be achieved through appropriate promotion and nutrition education programmes, e.g. promote as nutritionally rich traditional green leafy vegetables.

Promotion of kitchen garden / nutrition garden for more intake of greens

India is the richest source for vegetables and greens. A survey can be taken up to identify the non-traditional green leaves and their nutrient contents. The crops which are rich in nutrients can be commercially exploited. 
Breeding programme can be initiated in green leafy vegetables to increase the nutrient contents and reduce the anti-nutritional factors.

\section{References}

Abbas M, Shirin M, Patricia K, 2011. The effect of Hibiscus sabdariffa on lipid profile, creatinine, and serum electrolytes: a randomized clinical trial. International scholarly research network. ISRN gastroenterology. 2011:1-4.

Allemann J, Van Der Heever E and Viljoen A.1996. Evaluation of Amaranthus as a possible vegetable crop. Appl. Plant Sci; 10:1-4.

Bhandari P. Curry leaf (Murraya koenigii) or Cure leaf: Review of its curative properties. J. Med. Nutr. Nutraceuticals. 2012;2:92-97. doi: 10.4103/2278-019X.101295

Beaulah.A and S. Mariappan.2016. Moringa-Tree of life for preventing malnutrition among women and children. Inter. J. of Nutrition and Agriculture Research. 3(2), 2016, 34 43.

Britton G.1996. Carotenoids. In: Hendry GAF. Natural food colorants, Springer, USA; p. 197-243.

Candish.J.K,Gourley.L,Lee HP.1987. Dietary fibre and starch contents of some South East Asian Vegetables. J.Agri.Food Chem.35:319-21.

Chewonarin T, Kinouchi T, Kataoka K. 1999. Effect of rosell (Hibiscus sabdariffa), a Thai medicinal plant, on the mutagenicity of various mutagens in Salmonella typhnumurium and on formation of aberrant Crypt Foci induced by the colon carcinogens azoxymethane and 2-amino-1methyl-6-phenylimidazo [4,5-b] pyridine in F344 rats. Food and Chemical Toxicology. 1999; 37(6): 591-601.

Diane Feskanich, Peter Weber, Walter C Willett, Helaine Rockett, Sarah L Booth and Graham A Colditz. 1999.Vitamin K intake and hip fractures in women: a prospective study. The American Journal of Clinical Nutrition, Volume 69, Issue 1, January 1999 ,

$$
\text { Pages }
$$

74-79, https://doi.org/10.1093/ajcn/69.1.74

Edelman M and Colt M. 2016. Nutrient value of leaf vs. seed. Front Chem. 2016;4:1-32.

Folkard G and Sutherland J. Moringa oleifera: a tree with enormous potential, Translated from Agroforestry Today, 8(3), 1998, 5-8.

Fugile, L. J. 2003. The Moringa tree local solution to malnutrition. Darker Sebegal.

Guillet D.2004. Grain Amaranthus, History and Nutrition. Kokopelli Seed Foundation $<$ http:// www.kokopelli-seedfoundation.com/amaranthus.htm>

Gupta AK, 2014. Alternanthera sessilis. The IUCN Red List of Threatened Species. Version 2014. http://www.iucnredlist.org

Holm LG; Doll J; Holm E; Pancho JV; Herberger JP, 1997. World Weeds: Natural Histories and Distribution. New York, USA: John Wiley and Sons Inc.

Jenkins DJ, Kendall CW, Popovich DG 2001. Effect of a very-high-fiber vegetable, fruit, and nut diet on serum lipids and Colonic function. Metabolism. 2001;50(4):494-503.

Irène Ahou Kouadio. I.A, M. K. Koffi and G. A. Konan, 2019. Nutritional intake of Solanum nigrum Linn. leaves fortified with peanut paste consumed at breakfast in rural zones in Côte d'Ivoire. Int. J. Biol. Chem. Sci. 13(2): 586-596, April 2019

Laribi.B, Karima Kouki' Mahmoud M'Hamdi' Taoufik Bettaieb. 2015. Coriander (Coriandrum sativum L.) and its bioactive constituents. Fitoterapia,. 2015 Jun;103:926. doi: 10.1016 .

Mensah, J. K., Okoli, R. I., Ohaju- Obodo, J. O., and Eifediyi, K. 2008. Phytochemical, nutritional and medical properties of some leafy vegetables consumed by Edo people of Nigeria. African Journal of Biotechnology, 7(14), 2304-2309

Muthaliar. M, Siddha.1998. Materia Medica (Vegetable section), Volume I, Fourth edition, Publisher; (1988), Tamilnadu Siddha Medical Council, Chennai

Ofusori, D. A., Adelakun, A. E., Ayoka, A. O., Oluwayinka, O. P., Omotoso, E. O., Odukoya, S. A., and Adeyemi, D. O. 2008. Waterleaf (Talinum triangulare) enhances cerebral functions in Swiss albino mice. Journal of Neurological Sciences, 25(4), 239-246. 
http://www.jns.dergisi.org/text.php3?id=24 1

Ogie- Odia, E. A., and Oluowo, E. F. 2009. Assessment of some therapeutic plants of the Abbi People in Ndokwa West L.G.A. of Delta State. Nigeria. Ethnobotanical Leaflets, 13, 989-1002.

Ogunlesi, M., Okiei, W., Azeez, L., Obakachi, V., Osunsanmi, M., and Nkenchor, G. 2010. Vitamin $\mathrm{C}$ contents of tropical vegetables and foods determined by voltammetric and titrimetric methods and their relevance to the medicinal uses of the plants. International Journal of Electrochemical Sciences, 5, 105-115.

Oguntona, T. 1998. Green leafy vegetables In Osagie A. U., and Eka O. U. (Eds.), Nutritional quality of plant foods (pp. 120 133). Nigeria: Post harvest research unit, Department of Biochemistry, University of Benin, Benin city.

Padhee.K.Arabinda and Joanna Kane-Potaka, 2020. COVID-19 calls for renewed focus on eating right and natural. Down to Earth Magazine.

Palaniswamy UR, Bible BB, McAvoy RJ. Effect of nitrate: ammonium nitrogen ratio on oxalate levels of purslane. Trends in New Crops and New Uses. 2002; 11(5):453-455.

Petrus, A.J.A. 2013.Sauropus androgynus (L.) Merrill- A potentially nutritive functional leafy-vegetable. Asian J. Chem., 2013, 25, 9425-9433.

Pradheep Karmarkar, Vikas Singh, RB. Yadava, B. Singh, Rameswar Singh and Motilal Kushwaha. 2016.Agathi (Sesbania grandiflora): Current status, production, protection and genetic improvement. National Symposium on vegetable legumes for soil and human health Feb 12-14, 2016. Rao.T.V and Tuhina.2002. Iron, calcium, beta carotene, ascorbic acid and oxalic acid content of some less common leafy vegetables consumed by tribals. J.Food Sci.Tech. 2002:39:560-2

Sanderson, Helen, Renfrew and Jane M. 2005. Prance, Ghillean; Nesbitt, Mark (eds.). The Cultural History of Plants. Routledge. p. 114. ISBN 0415927463

Sreenivasa Rao Jarapala.2017. Nutrition Science in India: Green leafy vegetables: A potent food source to alleviate micronutrient deficiencies. International Research Journal of Basic and Applied Science. 2017; ISSN No. 2455-6718.

Srinivasan, 2006. Fenugreek (Trigonella foenumgraecum): A review of health beneficial physiological effects. Food Rev. Int., 22 (2) (2006), pp. 203-224

Stephen Daniells.2008. Green Leafy Vegetables may halve lung cancer risk. Nutra Ingredients.- USA.com. News letter.

Wang J.-B., Fan J.-H., Dawsey S.M., Sinha R., Freedman N.D., Taylor P.R., Qiao Y.-L., Abnet C.C. Dietary components and risk of total, cancer and cardiovascular disease mortality in the linxian nutrition intervention trials cohort in china. Sci. Rep. 2016;6:22619. doi: 10.1038/srep22619.

Yankuzo H., Ahmed Q.U., Santosa R.I., Akter S.F.U., Talib N.A. Beneficial effect of the leaves of Murraya koenigii (Linn.) Spreng (Rutaceae) on diabetes-induced renal damage in vivo. J. Ethnopharmacol. 2011; 135: 88-94. doi: 10.1016/j.jep.2011.02.020

\section{How to cite this article:}

Beaulah, A., C. Rajamanickam and Swaminathan, V. 2020. Nutritive Values and Importance of Tropical Green Leafy Vegetables in Human Diet - A Review. Int.J.Curr.Microbiol.App.Sci. 9(09): 656-669. doi: https://doi.org/10.20546/ijcmas.2020.909.083 